\title{
Strategic human resource management in the Brazilian Federal Legislative: conditions for the implementation
}

\author{
Felipe Guimarães Côrtes ${ }^{1}$ \\ Pedro Paulo Murce Meneses ${ }^{2}$ \\ 1 Instituto Brasiliense de Direito Público / Escola de Administração de Brasilia, Brasília / DF — Brazil \\ ${ }^{2}$ Universidade de Brasília / Programa de Pós-Graduação em Administração, Brasília / DF — Brazil
}

\begin{abstract}
This research aimed to identify interfering aspects in the implementation of strategic human resource management in Brazilian Federal Legislative bodies, as well as the possible relations between them. Through interviews and focus groups with 16 managers of the Federal Senate and the Chamber of Deputies, 21 interfering aspects were identified, divided into institutional, political, organizational, and sectoral categories. The study elaborated theoretical-empirical models of the influences exerted by each of the aspects on the others, which supported the conclusion that the most significant constraints are of political nature, since they would define the resources and the autonomy available to human resource management units to lead the implementation process.
\end{abstract}

Keywords: strategic human resource management; human resource management in public administration; human resource management in the Legislative Power.

\section{Gestão estratégica de pessoas no Legislativo Federal brasileiro: condições para a implementação}

Esta pesquisa objetivou identificar aspectos interferentes na implementação da gestão estratégica de pessoas (GEP) nos órgãos do Poder Legislativo Federal brasileiro e as possíveis relações entre eles. Por meio de entrevistas e grupos focais realizados com 16 gestores do Senado Federal (SF) e da Câmara dos Deputados (CD) foram identificados 21 aspectos interferentes, divididos em categorias institucionais, políticas, organizacionais e setoriais, bem como foram elaborados modelos teórico-empíricos das influências exercidas por cada um dos aspectos sobre os demais, a partir do que se concluiu que os condicionantes mais significativos teriam natureza política, pois definiriam os recursos e a autonomia disponíveis para as unidades de gestão de pessoas (GP) conduzirem o processo de implementação.

Palavras-chave: gestão estratégica de pessoas; gestão de pessoas na administração pública; gestão de pessoas no Poder Legislativo.

\section{Gestión estratégica de personas en el Legislativo Federal brasileño: condiciones para la implementación}

Esta investigación se propuso identificar aspectos interferentes en la implementación de la gestión estratégica de personas en los órganos del Legislativo Federal brasileño y las posibles relaciones entre ellos. Por medio de entrevistas y grupos focales realizados con 16 gestores del Senado Federal y de la Cámara de Diputados, se identificaron 21 aspectos interferentes, divididos en categorías institucionales, políticas, organizativas y sectoriales, así como se elaboraron modelos teórico-empíricos de las influencias ejercidas por cada uno de los aspectos sobre los demás, a partir de lo que se concluyó que los condicionantes más significativos tendrían naturaleza política, pues definirían los recursos y la autonomía disponibles para que las unidades de gestión de personas conduzcan el proceso de implementación.

Palabras clave: gestión estratégica de personas; gestión de personas en la administración pública; gestión de personas en el Poder Legislativo. 


\section{INTRODUCTION}

In order to meet the growing demands for accountability and resource efficiency, during the last half of the twentieth century, most notably in the 1980s and 1990s, a number of governments in different countries initiated reforms, to a greater or lesser extent, in a movement called New Public Management (Hall \& Holt, 2008; Hammerschmid \& Walle, 2011; Hood, 1991; Peci, Pieranti, \& Rodrigues, 2008).

Initiated in the United Kingdom and disseminated to other European nations and countries such as the United States of America, Australia and New Zealand, this movement can be seen as the growing concern of the public sector to acquire characteristics normally associated with the productive sectors of the economy (Hall \& Holt, 2008; Hammerschmid \& Walle, 2011; Motta, 2013).

As a result of these reforms, Truss (2008) points out that human resources management (HRM) in the public sector has received renewed attention, since new approaches in the area could facilitate the recruitment and selection of qualified teams, improve the effectiveness of organizational costs and serve as propellants for a performance-driven culture.

Thus, HRM practices derived from private initiative were established as models, among which we can highlight: performance-based rewards; reduction of employment costs; strategic decentralization for human resources units; greater flexibility; and increased individualization of labor relations (Truss, 2008).

Hence, there have been efforts in the public sector towards the adoption of a strategic human resources management (SHRM), understood as that one that unites with the decision makers and integrates the organizations long term objectives with people's related needs (Lacombe \& Tonelli, 2001; Marler \& Fisher, 2013; Truss, 2008).

In Brazil, one of the consequences of the reforms introduced during the decade of 1990, is the attempt of conduction of HRM's practices in the agencies of the Federal Executive, with emphasis in performance, results and excellency in service delivery. That reform, put in place motivation mechanisms and emphasis in the training of the public servers, as it was the case of the National Personnel Development Policy (NPDP), based in the competency-based management model (CBM), one of the possible strategic strands of HRM (Camões, Fonseca, \& Porto, 2014).

With few positive results after-implantation, the NPDP was an object of study of two recent Brazilian researches: one analyzed the influence of the autonomy of the HRM's units of the Federal Public Administration in well-succeeded accomplishment of activities of training and development, identifying contingencies to the achievement of these (Fonseca, 2013). The other study, described the main interfering factors in the implementation of this policy (Camões, 2013; Camões \& Meneses, 2016).

Conclusively, the identified factors and contingencies demonstrate the practical difficulty to transpose a model coming from the private initiative to the public sector, despite adopting as criteria only one of the possible sources of the HRM (training) and in only one sphere of the Public Administration, which is, the Federal Executive (Fonseca, Meneses, Silva, \& Campos, 2013).

There are international studies on the application of the SHRM and the HRM in the context of the public sector. It is possible to mention as one of the first studies of the genre the one developed by Mesch, Perry and Wise (1995). In the United States federal government, it identified as determinative factors for the well-succeeded implantation of the SHRM: degrees of decentralization, variability of 
HRM policies and participation of the line controlling, in addition to the focus given to the practices and policies of HRM (processes vs results).

Other theoretical-empirical studies, for example, in Belgium, Canada, the UK and U.S.A., had identified interfering factors as political influence (Brans \& Hondeghem, 2005), support of the management (Bonder, Bouchard, \& Bellemare, 2011), key-agent's influence (Truss, 2008) and skills of the HRM's Director (Jacobson, Sowa, \& Lambright, 2014), respectively.

As all these researches concerned the Executive, evaluations still need to be done to determine if such factors and difficulties would also appear in other fronts of the Public Administration, which is the case of the Brazilian Congress, which is not conditioned to the adoption of the NPDP and in which, according to Lamari (2010), it did not have any consistent concern in regards to innovation and public administration.

Presumably, the managerial and administrative reforms had not caused relevant effects in the HRM of the Congress, whose permeability to political factors seems to have favored the prevalence of patrimonialist management practices instead of others more strategic. These were not undertaken not as part of an institutional plan, but as managers own initiative (Cinnanti, 2011; Guimarães, Schwartz, Souza, Melo, \& Teixeira, 2012; Guimarães, Schwartz, Werneck, \& Melo, 2015).

Focused mainly in the legislative functioning and process, the studies in this field still have unexplored dimensions, they are also relatively recent, dating back from the last 20 years. In Brazil, the majority of these studies approaches the formal legal initiative and the consequences analysis of the prevalence of the Executive's legislative agenda, in contrast to the small amount of inquiries concerning the aspects of the organizational culture and the peculiarities of the legislative houses (Araújo \& Silva, 2012; Inácio \& Rennó, 2009).

Hence, when conjugated with the relative scarcity of research on the SHRM in the Brazilian public sector, it is imperative the need of inquiries concerning the implementation, in the context of the Chamber of Deputies (CD) and the Federal Senate (SF), of the principles of the SHRM (Armond, Côrtes, Santos, Demo, \& Meneses, 2016).

Therefore, this research aimed to contribute theoretically for the field of the Public Administration filling a gap concerning the HRM in the Legislative - environment that presents particularities in its internal configuration. Moreover, it gives continuity to a line of academic inquiries concerning the SHRM in the public sector, whose peculiarities, tensions and ambiguities add, apparently, a layer of complexity in the stage of implementation (Brown, 2004; Truss, 2008).

As such, this study had as a goal the identification of interfering aspects in the adoption of the principles of the SHRM in Brazilian Federal Legislative and, additionally, the establishment of hypothetical-deductive models of possible relations between these aspects, that can guide future inquiries on similar topics and initiatives of the managers of people in this context, as well as, given the proportions, in organizations of other powers.

\section{STRATEGIC HUMAN RESOURCES MANAGEMENT}

In spite of the debate concerning the meaning of the SHRM, there's a common point of view shared by different researchers: the notion that the activities of HRM must be integrated and put in a broader context (Jackson, Schuler, \& Jiang, 2014). 
This concept of integration, distinctive element of the SHRM, would have four components: alignment with the strategy of management and the process of strategic planning; the coherence between the policies of HRM and these with the other organizational policies; the alignment of the attitudes and the behaviors of the managers in regards to the HRM; and the alignment of the labor force with the organizational business (Guest, 1987).

In practice, the conception of these four components would have to be based on the analysis of a series of aspects: the composition of the human capital resources stock (skills and capabilities), the specification of the required behaviors of the work force and the effectiveness, in terms of results, of the decisions ahead of the organizational strategies, in addition to the institutional and political factors who influence the HRM (Wright \& McMahan, 1992).

In summary, the SHRM figures as the rethinking of the policies, subsystems, practices and activities of HRM, in order to assume a strategic integration with the organizational objectives (vertical alignment) and an internal cohesion to the HRM function (horizontal alignment), taking into account environmental variables and different actors involved, to facilitate the implantation of the plans of the organization and to trigger its results and its resilient capacity (Cascio, 2015; Lacombe \& Tonelli, 2001; Leite \& Albuquerque, 2011; C. A. Lengnick-Hall, Beck, \& M. L. Lengnick-Hall, 2011).

Historically, according to the review of the literature produced from the early 1980 s to the mid2000s by M. L. Lengnick-Hall, C. A. Lengnick-Hall, Andrade and Drake (2009), the field of research of the SHRM passed through different evolutionary periods. This was organized by the authors in 7 great clusters, as detailed in the Box 1.

BOX 1 SEVEN MAIN HISTORICAL RESEARCH SUBJECTS IN THE FIELD OF THE SHRM

\begin{tabular}{|c|c|}
\hline Thematic & Core concept \\
\hline $\begin{array}{l}\text { Explaining contingency perspectives } \\
\text { and fit }\end{array}$ & $\begin{array}{l}\text { Particular sets of HRM tend to have better performance when combined with specific } \\
\text { objectives, conditions and strategic interests. }\end{array}$ \\
\hline $\begin{array}{l}\text { Shifting from a focus on managing } \\
\text { people to creating strategic } \\
\text { contributions }\end{array}$ & $\begin{array}{l}\text { Paradigm shift in the traditional human resources administration to one based on the } \\
\text { contributions of the human capital, strategic capacities and competitive organizational } \\
\text { performance, in addition to the change of paper of the HRM professional. }\end{array}$ \\
\hline $\begin{array}{l}\text { Elaborating HR system components } \\
\text { and structure }\end{array}$ & $\begin{array}{l}\text { Policies and practices of HRM are complex and interdependent processes that would not } \\
\text { have to be considered independently, but examined as subsystems or packages. }\end{array}$ \\
\hline Expanding the scope of SHRM & $\begin{array}{l}\text { Mindset change from the internal actions of the organization to those present in units of } \\
\text { business, groups of interest, chain of value and international context. }\end{array}$ \\
\hline SHRM implementation and & $\begin{array}{l}\text { Concerns with the company's ability to concretize SHRM practices and the expected } \\
\text { strategic results. }\end{array}$ \\
\hline Measuring outcomes of SHRM & $\begin{array}{l}\text { Determination of valid and representative measures of the activities of SHRM, concerning } \\
\text { questions such as performance and results. }\end{array}$ \\
\hline Evaluating methodological issues & $\begin{array}{l}\text { Important methodological concerns of the field's development and of the establishment of } \\
\text { a more complete conceptual frame and theoretical assumptions. }\end{array}$ \\
\hline
\end{tabular}

Source: Adapted from M. L. Lengnick-hall et al. (2009). 
A more recent review divided the research history differently, considering 4 main axis: aspects of the external and internal environments as antecedent of the HRM systems performance; links of the HRM systems with the results for diverse actors; mediating relations that bind HRM systems with the results for internal and external actors; and ambient conditions that restrict or potentialize the beneficial effect of the HRM systems (Jackson et al., 2014).

Theoretically, a seminal study carried out by Delery and Doty (1996) considered the categorization of the different clusters adopted in the research on SHRM until then in 3 possible perspectives, to depend on the used frameworks to understand the link between the organizational strategy and the system of HRM: universalist, contingency and configurational.

The universalist perspective assumes the existence of superior HRM practices, whose adoption would lead to better organizational results independently of the characteristics of the organizations and the environment in which they act. The contingency perspective assumes that certain practices of HRM are more effective when properly aligned with the organizational conditions, such as size, time of existence and applied technologies. Finally, for the configurational perspective, there are certain standard of HRM practices that are a better fit for each type of organization and its respective strategy.

Inserted in the subjects "Explaining contingency perspectives and fit" and "SHRM implementation and execution", suggested by M. L. Lengnick-hall et al. (2009), in the last axis delineated by Jackson et al. (2014), as well as derivatives of the contingency and configurational perspectives categorized by Delery and Doty (1996), there are also the contextual approaches of the SHRM, usually based on the idea that results are different than planned, due to environmental factors, as these generate unexpected challenges or changes for the organization (Hendry \& Pettigrew, 1990; Paauwe, 2004).

The concerns with the context where the HRM is inserted, both from the external and internal points of view of the organization, can be symbolized by the conceptual model of Hendry and Pettigrew (1990), represented in Figure 1. In this model, there are external factors, whose natures are socioeconomic, technical, political-legal and competitive, and interns, in relates to the culture, the structure, the politics/leadership, the technology of tasks and the organizational results, that would contribute for the characterization and the content of the HRM, in a close relation with the corporative strategy (Hendry \& Pettigrew, 1990).

Although generic, this model, by demonstrating the complexity of the adjustment between the organizational strategy and the policies of HRM, shows also the influence by diverse factors of the external and internal organizational contexts. Therefore, this model is useful for proposing and testing specific theoretical models adjusted to the Brazilian Public Administration's reality, especially considering that this sector, tending to the importation of consolidated principles and precepts in the private sector, focuses on results of public interest and not private, or private individuals, which may make it more difficult to transform the HRM unit into a strategic partner (Brown, 2004; Camões \& Meneses, 2016; Fonseca et al., 2013; Paauwe, 2004; Truss, 2008).

Outlined the theoretical frame of the research, the literature was carefully examined in search of scientific reports that indicated possible contextual aspects with impact for the implementation of the SHRM in the public sector, aiming to compose a reference scenario for the elaboration of the instrument of data's collection and posterior analysis, as described stages in the section of methodological procedures. The synthesis of the identified aspects and the framing of these in categories appears in Box 2. 


\section{FIGURE 1 CONTEXTUAL HRM MODEL}

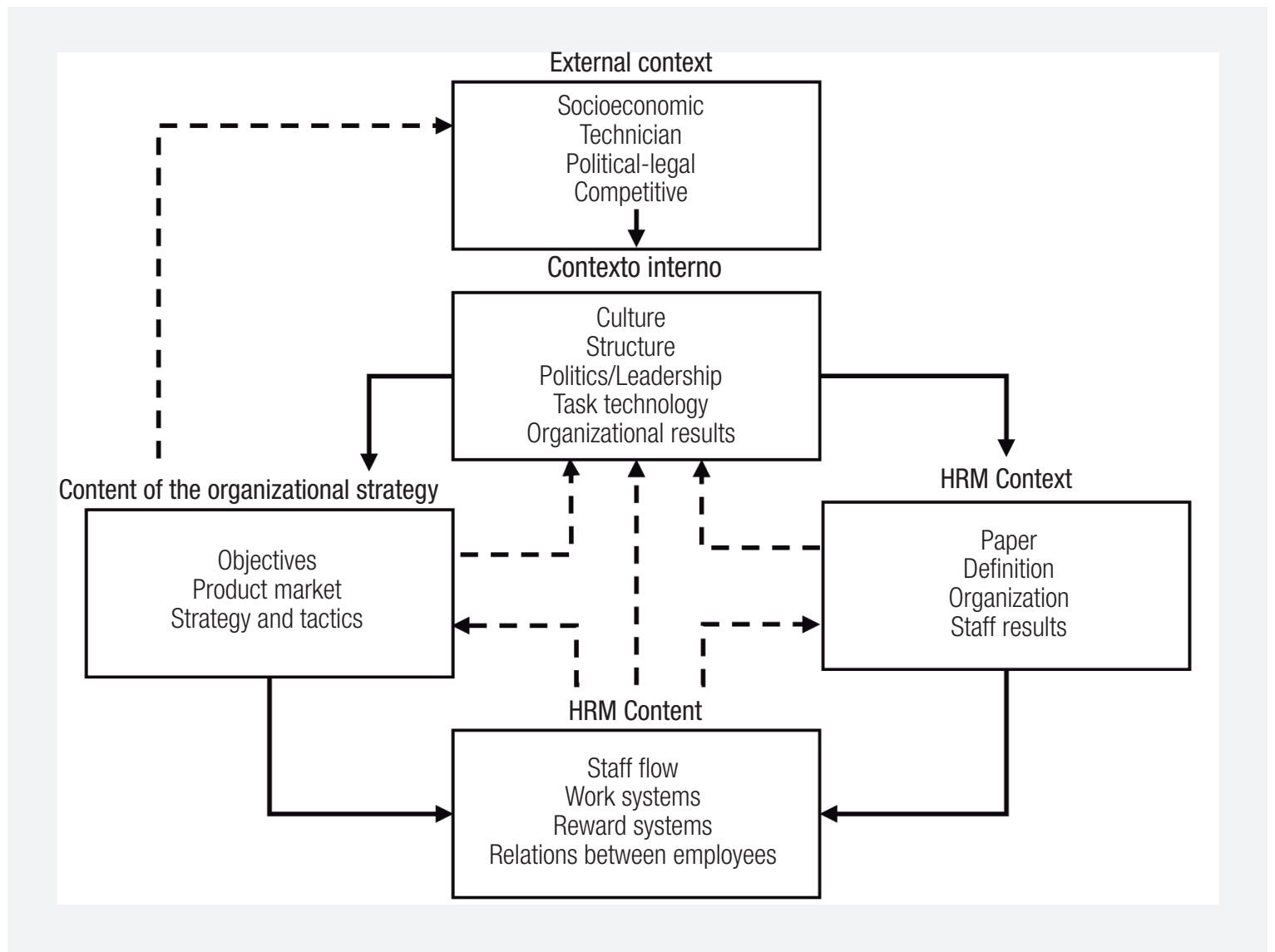

Source: Adapted from Hendry and Pettigrew (1990).

BOX 2 INTERFERING CATEGORIES AND ASPECTS IN THE SHRM OF THE BRAZILIAN FEDERAL LEGISLATIVE

\begin{tabular}{|c|c|c|}
\hline Categories & Aspects & References \\
\hline \multirow{3}{*}{ Institutional } & Societal characteristics & $\begin{array}{l}\text { Fonseca and Meneses (2016); Fonseca (2013); Fonseca et al. (2013); } \\
\text { Lodge and Hood (2003); Ring and Perry (1985); Truss (2008). }\end{array}$ \\
\hline & External legislation and norms & $\begin{array}{l}\text { Camões (2013); Camões and Meneses (2016); Camões et al. } \\
\text { (2014); Fonseca and Meneses (2016); Fonseca et al. (2013); } \\
\text { Šiugždinienè (2006); M. A. M. Lima and I. V. Lima (2013); Mello } \\
\text { and Amâncio (2010); Randma-Liiv and Järvalt (2011); Ring and } \\
\text { Perry (1985); Silva and Mello (2013); R. L. S. Souza (2004); } \\
\text { Teixeira, Bassotti and Santos (2013). }\end{array}$ \\
\hline & Mechanisms of external control & $\begin{array}{l}\text { Järvalt and Randma-Liiv (2010); Ring and Perry (1985); Teixeira et } \\
\text { al. (2013). }\end{array}$ \\
\hline
\end{tabular}


RAP $\quad$ Strategic human resource management in the Brazilian Federal Legislative: conditions for the implementation

\begin{tabular}{|c|c|c|}
\hline Categories & Aspects & References \\
\hline \multirow{4}{*}{ Politics } & $\begin{array}{l}\text { Political configuration of the } \\
\text { organization }\end{array}$ & $\begin{array}{l}\text { Anselmi, Lazzini and Zarone (2013); Bergue (2014); Camões } \\
\text { (2013); Camões and Meneses (2016); Fonseca et al. (2013); } \\
\text { Harris (2005); Hondeghem, Horton and Scheepers (2006); } \\
\text { Ingraham and Rubaii-Barrett (2007); Järvalt and Randma-Liiv } \\
\text { (2010); Ring and Perry (1985); Šiugždinienè (2006); Teixeira et al. } \\
\text { (2013); Truss (2008). }\end{array}$ \\
\hline & Support of the high administration & $\begin{array}{l}\text { Bergue (2014); Camões et al. (2014); Fonseca and Meneses } \\
\text { (2016); Fonseca (2013); Järvalt and Randma-Liiv (2010); Lem } \\
\text { (2011); Randma-Liiv and Järvalt (2011); Šiugždinienė (2006); } \\
\text { Terabe and Bergue (2014); Truss (2008). }\end{array}$ \\
\hline & Administrative discontinuity & $\begin{array}{l}\text { Camões (2013); Camões and Meneses (2016); Fonseca and } \\
\text { Meneses (2016); Fonseca (2013); Järvalt and Randma-Liiv } \\
\text { (2010); Ring and Perry (1985); Teixeira et al. (2013). }\end{array}$ \\
\hline & Political skill of the HRM leadership & $\begin{array}{l}\text { Brans and Hondeghem (2005); Camões (2013); Camões and } \\
\text { Meneses (2016); Fonseca (2013); Fonseca et al. (2013); Ingraham } \\
\text { and Rubaii-Barret (2007); Jacobson et al. (2014). }\end{array}$ \\
\hline \multirow{7}{*}{ Organizational } & Strategic insertion of the HRM unit & Fonseca (2013); Ingraham and Rubaii-Barret (2007); Teo (2002). \\
\hline & Cultural characteristics & $\begin{array}{l}\text { Fonseca and Meneses (2016); M. . M. Lima and I. V. Rasp (2013); } \\
\text { Mello and Amâncio (2010); Silva and Mello (2013); Ubeda and } \\
\text { Santos (2008). }\end{array}$ \\
\hline & Organizational resources & $\begin{array}{l}\text { Camões (2013); Camões and Meneses (2016); Vo and Bartram } \\
\text { (2012). }\end{array}$ \\
\hline & Organizational structure & $\begin{array}{l}\text { Camões (2013); Camões and Meneses (2016); Daley and Vasu } \\
\text { (2005); Fonseca (2013); Fonseca and Meneses (2016); Fonseca } \\
\text { et al. (2013); Harris (2005); Ingraham and Rubaii-Barrett (2007); } \\
\text { Järvalt and Randma-Liiv (2010); Lodge and Hood (2003); Ring } \\
\text { and Perry (1985); Silva and Mello (2013); R. L. S. Souza (2004); } \\
\text { Teixeira et al. (2013); Truss (2008); Ubeda and Santos (2008); Vo } \\
\text { and Bartram (2012). }\end{array}$ \\
\hline & Engagement of managers and servers & $\begin{array}{l}\text { Bergue (2014); Bonder et al. (2011); Camões (2013); Camões and } \\
\text { Meneses (2016); Farnham and Stevens (2000); Fonseca (2013); } \\
\text { Hondeghem et al. (2006); Mesch et al. (1995); Silva and Mello } \\
\text { (2013); Teo (2002); Terabe and Bergue (2014); Ubeda and Santos } \\
\text { (2008). }\end{array}$ \\
\hline & Institutional communication & $\begin{array}{l}\text { Farnham and Stevens (2000); Harris (2005); Lodge and Hood } \\
\text { (2003); Pichault (2007); Ring and Perry (1985); Silva and Mello } \\
\text { (2013). }\end{array}$ \\
\hline & Internal norms & Guimarães et al. (2012). \\
\hline
\end{tabular}




\begin{tabular}{|c|c|c|}
\hline Categories & Aspects & References \\
\hline \multirow{7}{*}{ Sectoral } & Strategic integration of HRM & $\begin{array}{l}\text { Camões (2013); Camões and Meneses (2016); Fonseca and } \\
\text { Meneses (2016); Järvalt and Randma-Liiv (2010); Lem (2011); } \\
\text { M. A. M. Lima and I. V. Lima (2013); Mello and Amâncio (2010); } \\
\text { Mesch et al. (1995); Pichault (2007); Ring and Perry (1985); } \\
\text { Teixeira et al. (2013); Ubeda and Santos (2008). }\end{array}$ \\
\hline & Reputation of the HRM unit & $\begin{array}{l}\text { Fonseca (2013); Fonseca et al. (2013); Ingraham and Rubaii- } \\
\text { Barrett (2007); Jacobson et al. (2014); Ring and Perry (1985); Teo } \\
\text { (2002). }\end{array}$ \\
\hline & Resources of the HRM unit & $\begin{array}{l}\text { Bergue (2014); Camões (2013); Camões and Meneses (2016); } \\
\text { Farnham and Stevens (2000); Fonseca (2013); Fonseca and } \\
\text { Meneses (2016); Mello and Amâncio (2010); Šiugždinienė (2006); } \\
\text { R. L. S. Souza (2004); Terabe and Bergue (2014); Vo and Bartram } \\
\text { (2012). }\end{array}$ \\
\hline & Autonomy of the HRM unit & $\begin{array}{l}\text { Camões (2013); Camões and Meneses (2016); Fonseca et al. } \\
\text { (2013); Järvalt and Randma-Liiv (2010); Mesch et al. (1995); } \\
\text { Teixeira et al. (2013); Vo and Bartram (2012). }\end{array}$ \\
\hline & Structure of the HRM unit & Ubeda and Santos (2008). \\
\hline & Implementation methodology & $\begin{array}{l}\text { Boyett and Currie (2001); Camões (2013); Camões and Meneses } \\
\text { (2016); Fonseca et al. (2013); Fonseca and Meneses (2016); } \\
\text { Hondeghem et al. (2006); Lem (2011); Pichault (2007); Ring and } \\
\text { Perry (1985); Šiugždiniené (2006); Truss (2008). }\end{array}$ \\
\hline & $\begin{array}{l}\text { Coexistence of the functional role of } \\
\text { HRM }\end{array}$ & $\begin{array}{l}\text { Fonseca et al. (2013); Mello and Amâncio (2010); Mesch et al. } \\
\text { (1995); Teo (2002); Vo and Bartram (2012). }\end{array}$ \\
\hline
\end{tabular}

Source: Elaborated by the authors.

Therefore, the category of institutional interferants embraces environmental elements which are external to the public organizations and influence their functioning, its structure and the orientation of its activities and, obviously, the policies and practices of HRM (Fonseca, 2013). The political ones derive from the intra and intergroups dynamics and relationships, being associated to the formation of agenda and decision making regarding elements like power, use of influence, conflict of interests, construction of coalitions, negotiation and bargain (Camões \& Meneses, 2016).

The interferants of the organizational category, in their turn, compose the internal environment of the public organizations, showing in its internal organization, hierarchic structure, organizational culture, interpersonal relations and processes. Finally, the sectoral ones are related to elements under direct control of the HRM unit and aspects that define what comes from the performance style and the attributes and skills of its controller and its team (Fonseca, 2013).

To fulfill with the objectives of this research, that is, to verify which facilitators and restrictions are in the agencies of the Brazilian Federal Legislative, the principles of the SHRM related to the vertical and horizontal alignments, the aforementioned categories (institutional, organizational, sectoral and political) and the actors (groups of interest and high administration) that influences the policies and practices of HRM were inserted in an adaptation of the proposal of Hendry and Pettigrew (1990), culminating in the elaboration of a model (Figure 2) that guided this inquiry. 

FEDERAL LEGISLATIVE

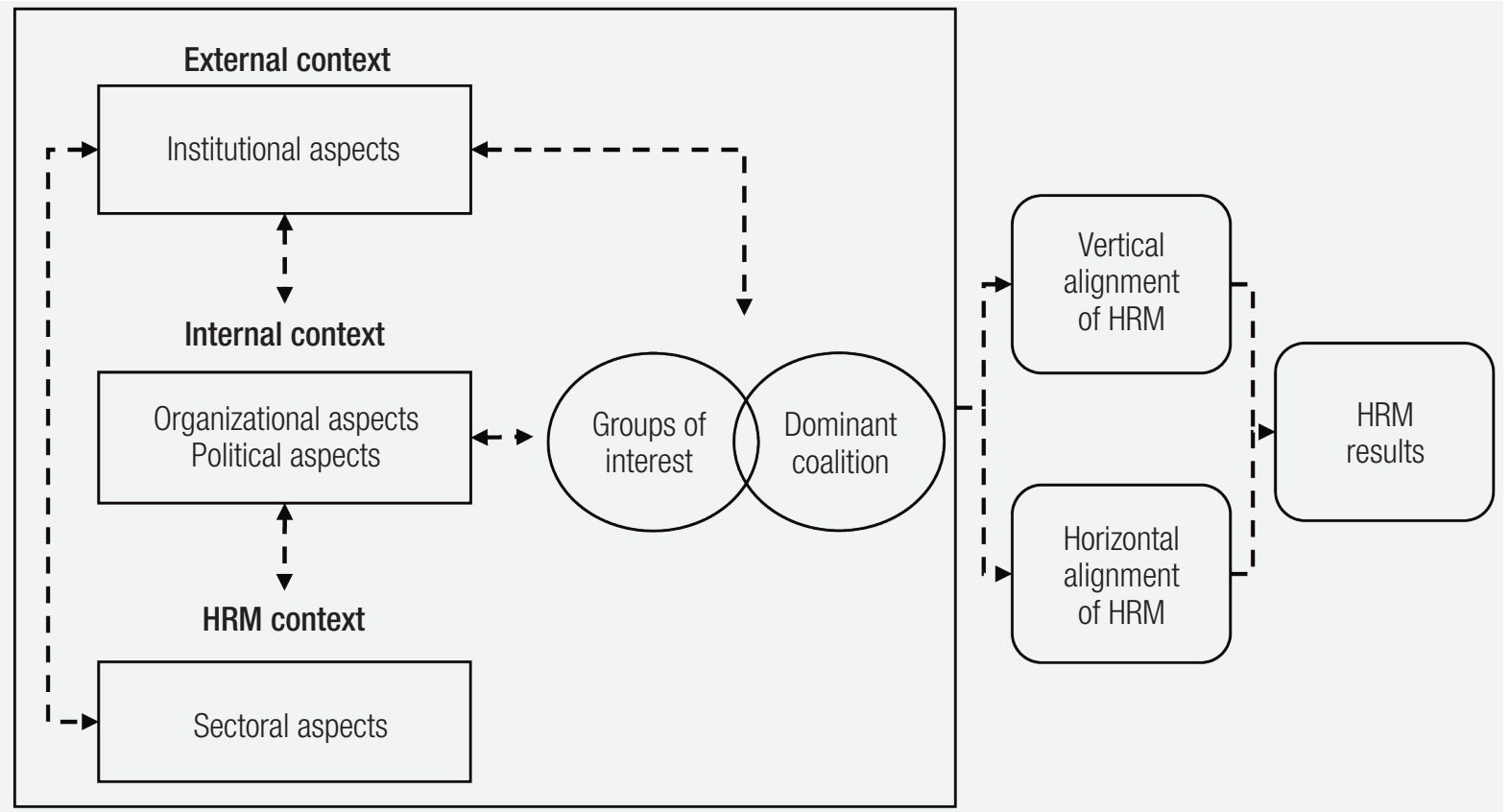

Source: Elaborated by the authors.

The aspects of the institutional category were framed as belonging to the external context of the model of Hendry and Pettigrew (1990); the organizational and the political ones, to the internal context of the same model; and the sectoral, the proper ones of the unit of HRM, had been considered part of the context of HRM defined by the authors.

The 3 types of context and the 4 types of interferants apparently would affect each other, in a complex system of interactions (Fonseca et al., 2013; Hendry \& Pettigrew, 1990; Paauwe, 2004), that also involves organizational actors, as the high administration (Bergue, 2014), groups of interest in general (Järvalt \& Randma-Liiv, 2010; Truss, 2008; Tsui, 1987), line managers (Guest, 1987; Mesch et al., 1995; Teo, 2002) and servers (Camões \& Meneses, 2016; Vo \& Bartram, 2012).

The result of these interactions and the action of diverse actors would intervene in the strategic integration of the area, relatively to its levels of horizontal and vertical alignment (Camões \& Meneses, 2016; Fonseca, 2013; Guest, 1987; Paauwe, 2004; Wright \& McMahan, 1992), what, in turn, would be one of the determinants of the results of the policies and practices of HRM (Guest, 1987; Paauwe, 2004).

The methodological choices, the elaboration of the instruments and the analysis of data of this study had been based on this model, above all in the categorization of predefined interferants, in order to allow the verification of which conditionings are present in the Brazilian Federal Legislative, how they relate to each other and how these interactions affect the vertical and horizontal alignments of the HRM and, consequently, their results. 


\section{METHODOLOGICAL PROCEDURES}

The research carried out a survey, where the researcher gathers information of experienced people in some area of study, through data collection of their memories, experiences and ideas on determined field, since the specific objective involved the verification, based on the experience of individuals who work in the Legislative, of the existence of interfering factors in the implementation of the SHRM principles (Cooper \& Schindler, 2014).

The nature of the research was descriptive, with qualitative approach (Cooper \& Schindler, 2014; Creswell, 2014). The research universe embraced the two legislative federal houses of Brazil, the Chamber of Deputies and the Federal Senate, and the selection of the participants was carried through rigid sampling (Flick, 2007), since all were invited because of the managerial position that they occupied within the HRM unit, and the individuals from one agency had similar or equivalent functions to the ones of other agency, in order to get reports from whom who experienced the proximity with the organizational planning and the HRM and, therefore, were better able to know potential interfering aspects in the implementation of SHRM principles.

Aiming to retain the meaning given to the phenomenon for the different participants and to improve the results, the triangulation method was adopted in the collection of data through two different instruments (Tran, 2015): a semi structuralized script of interview and a script of focal group (Flick, 2007).

For the construction of the first instrument, constant subsidies of scientific reports have been used, identified by means of an exploratory search, about probable interferences of the context in the adoption of SHRM in the Public Administration. From the reading of this material, the sections that suggested possible interferences to the application of the SHRM in the public sector were extracted and organized in a spreadsheet, with later identification of contextual aspects by article, homogenization of names of the aspects and grouping of these, by similarity, in four categories: institutional; political; organizational; and sectoral (Box 2).

Such categories had been defined from the proposal of national researchers that have been engaged in the application of the subject, especially, in the Federal Executive (Camões \& Meneses, 2016; Fonseca, 2013), also observing the rules of categorization of Bardin (2011): mutual exclusion; homogeneity; relevancy; objectivity; and productivity.

Therefore, the first script was elaborated from the literature on SHRM principles and the related types of contingencies involved in their implementation in the public sector, in compliance with the model presented in Figure 2. Questions have been made in regards to the following topics: HRM objectives in the organizations; planning of the policies and practices of HRM; contribution of the HRM for the achievement of the organizational objectives; degree of alignment between HRM subsystems; environmental variables; and groups of interest with positive or negative interference to the conduction of HRM activities.

The focus group script was based on a hypothetical HRM implementation situation in the organizations studied, so that the participants were encouraged to exchange opinions about what difficulties they would face, what facilities they would find and how they would lead the change process if they composed the team responsible for the transition, all based on past experience and knowledge on the categories of interfering aspects listed in Box 2. 
After a pilot application to 2 individuals, to verify the suitability of the instrument, interviews were carried out to a total of 8 individuals, all effective servers, being 4 managers of the HRM unit of each house, while the 2 focal groups had been carried through with others 4 managers of each, culminating in a sample of 16 participants, whose demographic data is synthesized in Table 1.

\section{TABLE 1 BASIC DEMOGRAPHIC DATA OF THE PARTICIPANTS}

\begin{tabular}{c|ccc} 
Code & Sex & Time in the organization (in years) & Time in the management function (in years) \\
\hline Participant 1 & Masculine & 24 & 15 \\
Participant 2 & Masculine & 6 & 0,2 \\
Participant 3 & Feminine & 32 & 1 \\
Participant 4 & Feminine & 20 & 3 \\
Participant 5 & Masculine & 17 & 12 \\
Participant 6 & Masculine & 31 & 4 \\
Participant 7 & Masculine & 27 & 2 \\
Participant 8 & Masculine & 6 & 1,5 \\
Participant 9 & Masculine & 34 & 13 \\
Participant 10 & Feminine & 24 & 18 \\
Participant 11 & Masculine & 25 & 13 \\
Participant 12 & Masculine & 14 & 9 \\
Participant 13 & Masculine & 33 & 2 \\
Participant 14 & Masculine & 7 & 0,5 \\
Participant 15 & Feminine & 20 & 4 \\
Participant 16 & Masculine & 4 & 1,5
\end{tabular}

Source: Elaborated by the authors.

All the data collected were treated jointly and integrally, both in terms of agency of origin and instrument used in the collection, through pre-categorical content analysis, since the categories and respective aspects had been previously identified in the literature (Bardin, 2011).

Finally, after concluding the content analysis, the parts related to the identified aspects had been reevaluated to verify the relationships between them, what made possible the elaboration of theoretical-empirical models for the understanding of the HRM in the Brazilian Federal Legislative, as well as hypothetical-deductive for future inquiries concerning SHRM in the public sector. 
RAP $\quad$ Strategic human resource management in the Brazilian Federal Legislative: conditions for the implementation

\section{RESULTS AND DISCUSSION}

As aforementioned, this study focused initially in identifying the possible interferants in the implementation of the principles of the SHRM in the Brazilian Federal Legislative. From the gathered evidences, 21 aspects were identified, fitted in 4 types of categories mentioned in the section of theoretical reference (institutional, political, organizational and sectoral). This is demonstrated in Table 2, which also presents the total recurrence of each aspect in the speeches of interviewees and focus groups participants.

\section{TABLE 2 INTERFERING CATEGORIES AND ASPECTS IN THE SHRM OF THE BRAZILIAN FEDERAL LEGISLATIVE}

\begin{tabular}{|c|c|c|}
\hline Categories & Aspects & Total recurrence \\
\hline \multirow{3}{*}{ Institutional } & Societal characteristics & 28 \\
\hline & External legislation and norms & 23 \\
\hline & Mechanisms of external control & 17 \\
\hline \multirow{5}{*}{ Political } & Political configuration of the organization & 58 \\
\hline & Support of the high administration & 27 \\
\hline & Administrative discontinuity & 21 \\
\hline & Political skill of the HRM leadership & 13 \\
\hline & Strategic insertion of the HRM unit & 11 \\
\hline \multirow{6}{*}{ Organizational } & Cultural characteristics & 42 \\
\hline & Organizational resources & 29 \\
\hline & Organizational structure & 20 \\
\hline & Engagement of managers and servers & 20 \\
\hline & Institutional communication & 14 \\
\hline & Internal norms & 8 \\
\hline \multirow{7}{*}{ Sectoral } & Strategic integration of HRM & 23 \\
\hline & Reputation of the HRM unit & 20 \\
\hline & Resources of the HRM unit & 19 \\
\hline & Autonomy of the HRM unit & 12 \\
\hline & Structure of the HRM unit & 11 \\
\hline & Implementation methodology & 10 \\
\hline & Coexistence of the functional role of HRM & 10 \\
\hline
\end{tabular}

Source: Elaborated by the authors. 
The identified aspects are explained from the perspective of participants, with examples of its narrative, and, when necessary, argued using existing literature on the subject, as well as possible interferences that exert on other aspects. Depleted the detailing of the results concerning the aspects of each category, a hypothetical-deductive and theoretical-empirical model is presented in regards to the interferences fore mentioned.

Thus, amongst the institutional category aspects, the most cited by interviewees and focal group participants was the societal characteristics, in regards to the economic, macro politics and social conjuncture that must be considered in the case of the implementation of the principles of the SHRM in the Federal Legislative. Considering the current Brazilian scenario, such characteristics end up deviating the focus of the high leadership from HRM topics to of more urgent issues, which demands a permanent acting of the HRM unit for acquiring support from this group of agents (1), which is still more difficult due to the evident administrative discontinuity in this sphere of power. This, in turn, is also more accentuated due to the national political scenario and the consequent and recurring party compositions with roles in the Executive taken by for Senators and Deputies (2).

An external actor who certainly affects HRM is the media, the journalists, because we have a fish ball effect, as if you were a fish in an aquarium being always observed, in a transparent aquarium, and any thing that you try to improve the HRM can be well interpreted by the servers and can badly be seen by society. This is, because the media can distort an administrative fact [...] then, any good consideration that comes to mind gives a possibility or sometimes, it happens in fact that one definitive attitude would be very favorable, positive, to servers, to even meet the proper commitments of quality of life, it can be misunderstood by the media, spread by the media [...] if we take into account the three powers, the most criticized power is always the Legislative (Participant 2).

The participants also mentioned the questions related to the legislation and external norms, whose constant changes, excess and fragmentation generate an additional workload for HRM units. Although some legal innovations can help these units to mitigate the overlapping of technical criteria for political ones in its own decisions (3), others demand operational efforts of the units so that if it modifies routines and procedures, in detriment of the execution of strategic activities (4), which converges with the results of the Teo's researches (2002) in an organization of the Australian public sector. The excess and the fragmentation of external laws and norms that regulate the HRM tend to generate conflicts in the interpretation and application of these rules, difficulty on elaboration of internal norms that is not conflicting with the external ones (5), being able, still, to create barriers to the integration and the interdependence between the diverse subsystems of HRM (6), as well as points Camões et al. (2014).

The norms that are implemented, a provisory measure for the Executive, that tries to restrict admission or tries to modify rights to the next generations of public servers also impacts here inside, because you have to mold to the transition rules, because when considering the institution of the acquired right, when it has a legal alteration, not saying that you're going to retreat, but the new servers will be subordinated to that new rule, for example, the social security rule, of the complementary social 
security, then, has to do with a gain of knowledge and management, the one new rule, for you to implement it, and this is constant (Participant 8).

A final point highlighted by the participants, related to the category of institutional factors, referred to the mechanisms of external control, specifically to requests from audits of the courts of accounts, legal demands for mandatory service and the need to observe jurisprudential understandings. Direct reflections of the Brazilian legal and normative framework, these demands imply, similarly to the one noted in the previous aspect, the concentration of efforts of the HRM sectors in the legal-formal personnel issues raised in the recommendations and collections from control and judicial bodies, which tend to reduce the opportunity for innovative and strategic action by these sectors (7).

[...] The Supreme Court, that is, the Supreme Federal Court, sometimes need to interfere and take definitive positions that they plaster or disable the political managers, I say the high administration, as much of the Chamber as the Senate, has to fulfill the judicial order (Participant 3).

In general terms, one can notice that the aspects of the institutional category can affect pertaining aspects to other types of category, in special the political and the sectoral ones (to see Figure 3). Thus, it can be inferred that the external legal-normative body to the Legislative organizations and the external and judicial controls impact more the reality of the units of HRM, in its work rhythm, and its flexibility to innovate and promote structural changes, while economic, macro politics, social and media questions influence more the agenda of the controllers and the level of support that they use to supply to the units of HRM to the achievement of its practices and policies.

\section{FIGURE 3 THEORETICAL-EMPIRICAL MODEL OF INTERFERENCES EXERTED BY THE INSTITUTIONAL ASPECTS}

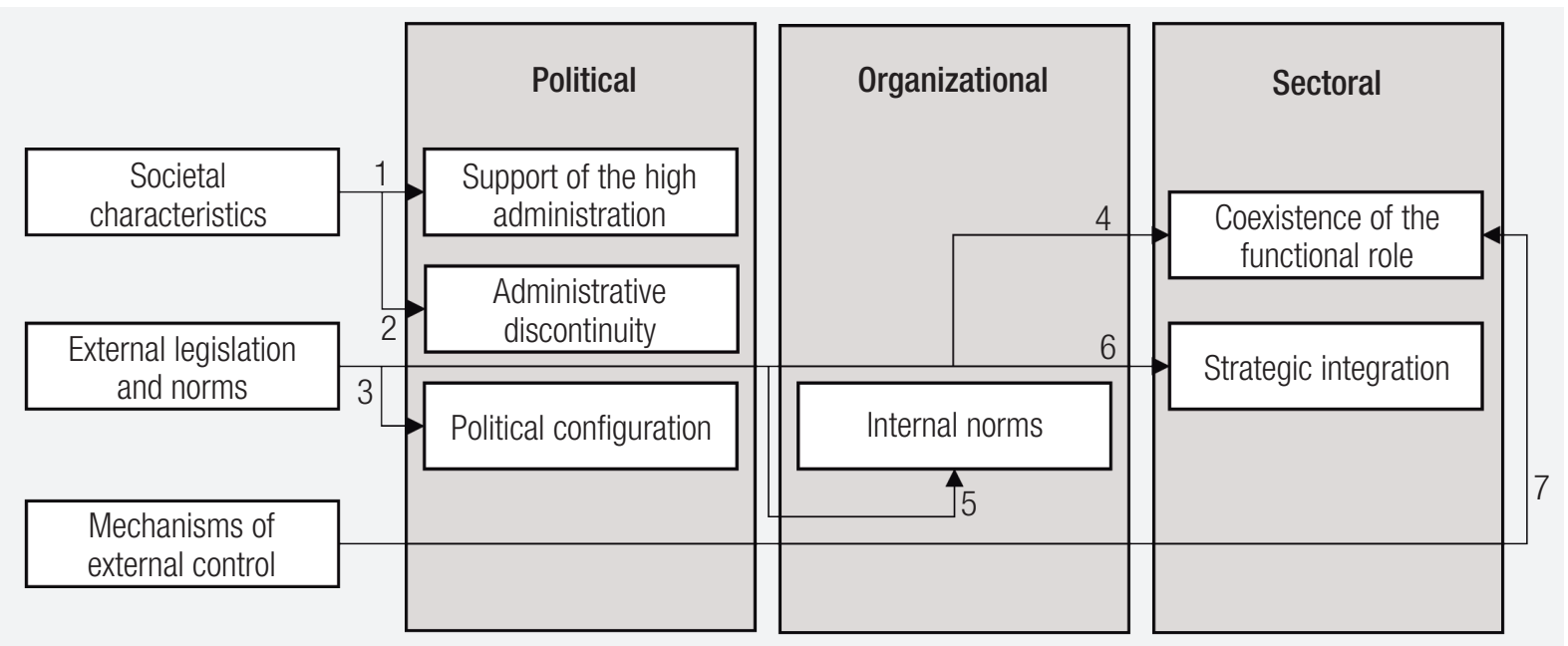

Source: Elaborated by the authors. 
In regards to the political category, the most mentioned aspect was the political configuration of the organization, concerning the standard of use of the influences and political criteria in the formation of the agenda of the high administration, once the proper nature of the legislative houses would generate administrative and decision-making processes, including HRM, much more inclined to negotiations and interferences of some groups of actors, frequently by criteria other than technical. This can cause low support of the high administration to the activities of the HRM unit (1) and, consequently, in decisions without bond with the organizational objectives, compromising the vertical alignment of the area (2).

[...] the HR does not take the decisions on the management of human resources [...] our greatest instance, is the Managing Board, even though we have a General-Direction, this sector reports to the Managing Board. Innumerable decisions that talk about the HRM in the house are taken by the Board, in other words, are political decisions (Participant 5).

Such conclusions are similar to the ones displayed by Ingraham and Rubaii-Barrett (2007), who assume as the one of the main problems of the HRM in the public sector exactly the overcoming of the different approaches and visions of the political agents and managers politically indicated relatively to the HRM controllers, which can harm the integration of the policies and practices of HRM to the organization's objectives.

The next aspect, intrinsically linked to the previous one, is the support of the high administration. The high administration of the houses of the National Congress has two instances: a purely administrative, that is General-Direction, and other of political-administrative character, called Directing Committee or Board. The reports demonstrate that, when such actors do not understand the HRM's importance for the fulfilment of the organizational intentions, it is impracticable that the HRM units, separately, try to implement the principles of the SHRM, similarly to what literature indicates, since for changes in HRM policies and practices, favorable decisions would be necessary on the part of these two groups to guarantee resources or autonomy (3), which would also help in obtaining greater engagement of servers and managers (4), because they would better accept the acting of the HRM unit (Fonseca \& Meneses, 2016).

[...] I would say that there is, usually, need for high administration, and why not say the Directing Board, and basically the First Secretary, who has this interface as the administrator, is... greater in the administrative question in relates to the server, is necessary that it has a fine tuning between the HRM unit and the First-Secretariat, and the sensitivity of this manager, of the First Secretary, in regards to the HR demands (Participant 3 ).

Another aspect is, in a certain manner, a consequence of the political configuration and even of a constitutional order on the duration of two years of the mandates of the Directing Committees of each one of the legislative houses is the administrative discontinuity. The general understanding is that, at each election of this collegiate, there are changes of the holders of the positions of DirectorGeneral and Director of the HRM unit, what can interrupt or modify cycles of the organizational strategic planning until then running and, thus, the priorities of the high administration (5) and even a cascade effect of abandonment or complete reformulations of long-term HRM projects, with possible losses to the HRM's level of strategic integration until then existing (6). 
$[\ldots]$ in regards to the administrative discontinuity is what we have followed in recent years, incessant exchanges of directors, that established policy does not even reach its first chapter of action, because in the following step the direction is substituted and there it goes there, you are always restarting, and I find that to restart you practically initiate a new procedure, that is never finished (Participant 13).

According to Ring and Perry (1985), one of the most important behaviors in the strategic processes management, with the objective of circumventing contextual factors and constraints, is precisely the attempt to manage and to minimize the discontinuity and the resulting gaps, through sensitivity to the political scenario, and it is important for managers, such as HRMs, to have technical knowledge and relationship skills in dealing with groups and actors involved in the creation and maintenance of alliances, such as political skills (7), which are the next aspect to be addressed.

This aspect, called the political skills of the HRM leadership, is seen by the participants under the prism of the influence capacities held by the leader of the HRM unit, used by him to persuade actors through negotiation processes. Such finding reaffirms the results of researches that point out as basic item in the implementation of the SHRM the role of the leadership in the demonstration, to the diverse groups of interest and to decision-making arenas, the strategic character and the importance of the HRM to the organizational performance (Jacobson et al., 2014).

[...] so HRM goes a long way for this ability you have of argumentation, persuasion, convincing, is... because all the, the, the groups are important there [...] normally, when you go to the General-Direction with a project, it is... or in the Directing Board, you speak like this: "are we going to invest in master's programs?", yes, because is not that expensive, when you transform this with names of people there, it is more complicated, so, I would say that the part of people who influence HR policies is the difficulty that I have to persuade... whenever you work with HRM you have two groups: you have the group above, that you have a great difficulty to convince, and you have to convince the servers of the importance of those programs too (Participant 7).

Thus, these skills of political nature of the HRM Director are important for him to be able to act well in higher instances, so that they can aid in the gradual transition from a functional to a strategic role in the public sector and in reversing a bad reputation (8) (Fonseca et al., 2013; I. G. L. Souza, 2016; Truss, 2008).

Finally, there is the aspect of strategic insertion of the HRM, whose references had fallen on the degree of participation of the HRM unit in the organizational planning or in the decisions on HRM policies, practices and projects, in addition to addressing the level of convergence of the area with the high administration. It was verified that this insertion is still incipient, being able to be worked so that there is a greater presence of its leaders or representatives in the arenas and in the decisionmaking processes of issues pertaining to the area, with greater autonomy (9), freedom for discussion, formulation, monitoring and review of proposals and plans (Ingraham \& Rubaii-Barret, 2007; Sheehan, Cieri, Cooper, \& Brooks, 2015). 
[...] At times, the decisions are taken and the norms are made, at times internally without hearing us, this sometimes impacts, and then creates a certain, a certain twist, creates a certain shudder, you have to bring everyone back (Participant 6).

Given the above and as illustrated in Figure 4, it is inferred that the political aspects, whose characteristics are in part molded by the institutional environment, also have effects between them, since the political configuration of the organization and the marked administrative discontinuity affect and integrate the complex decision-making process of the Federal Legislative Branch led by the high administration, with influence in the level of managers and servers engagement and HRM policies and practices that, to be strategicly integrated in an effective way, would need that all this political conjuncture was favorable, what apparently could be facilitated by the existence of a HRM leader who worked the reputation of the area.

\section{FIGURE 4 THEORETICAL-EMPIRICAL MODEL OF INTERFERENCES EXERTED BY THE POLITICAL ASPECTS}

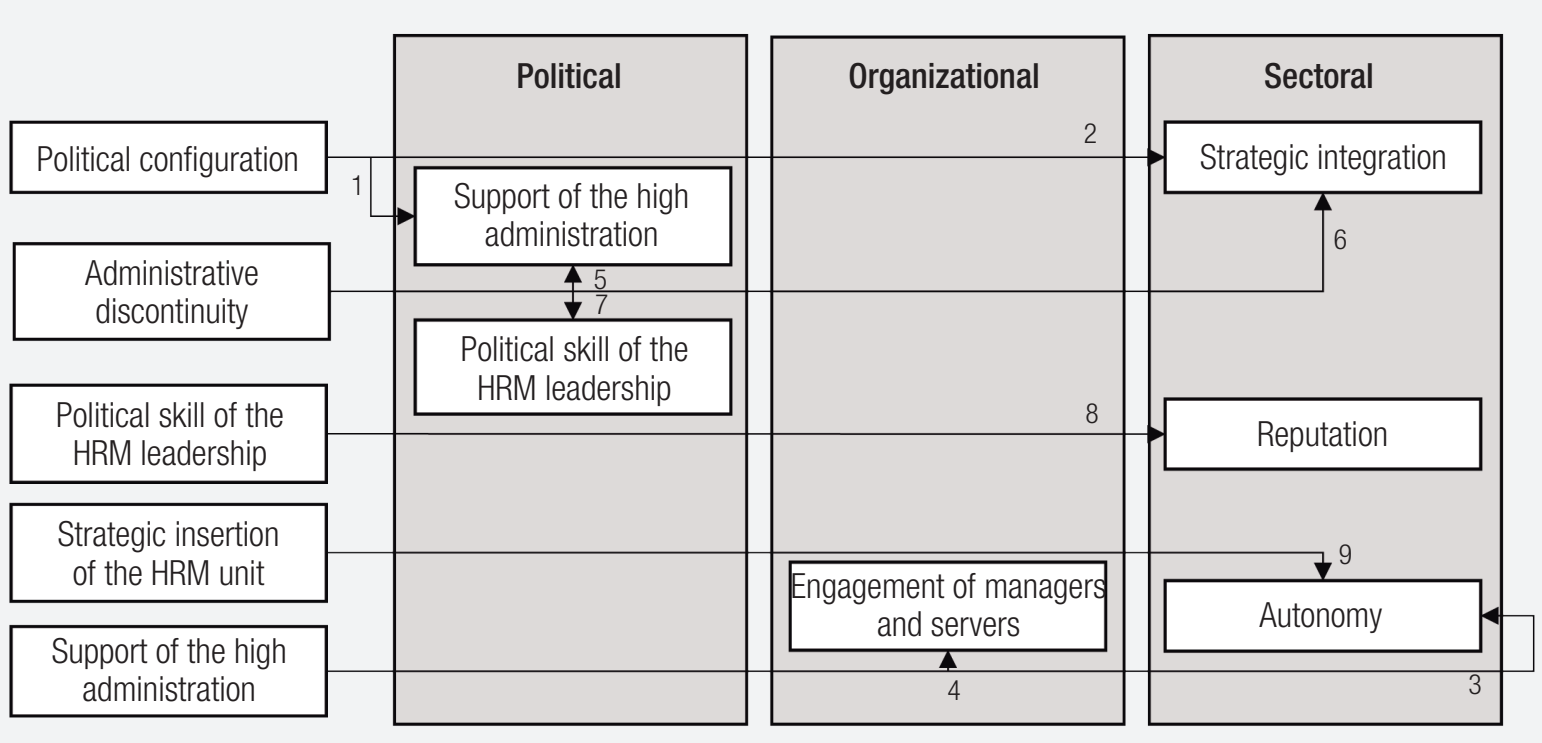

Source: Elaborated by the authors.

In regards to the organizational category, the most present aspect in the interviews were the cultural characteristics, with references to the difficulty of changing the established culture due to resistances and the tendency to accommodation by managers and servers, the differences in values between generations of servers and remnants of patrimonial values, with possible consequences for the engagement of managers and servers (1) and, consequently, for the level of strategic integration of the HRM (2). An example is the attempts made by one of the researched organizations to implement a more structured performance evaluation, linked to the organizational objectives, which failed exactly due to resistance of the servers. 
[...] we created a model, developed a system, applied in the department, and this model simply died [...] a gigantic effort of almost two years, trying to structuralize a HR model in the house [...] and that expired not for the political scene, but for our internal resistances (Participant 5).

Such findings are in line with the results of other researches in the Brazilian public sector, wich identified cultural barriers to the horizontal alignment between HRM subsystems, such as a purely formal and symbolic performance evaluation, due to the resistance of servers and managers to participate (M. A. M. Lima \& I. V. Lima, 2013), and also the existence of patrimonialis characteristics as difficulties in the effectiveness of strategic models of HRM (Silva \& Mello, 2013).

The following aspect, organizational resources, consisted of reports about disequilibrium in the amount of positions and functions, scarcity of servers, availability of computerized systems and budgetary and financial resources. For the participants, the high percentage of commissioned servers, demissible without motivation, can mean greater possibilities of discontinuity in long-term projects (3), as well as difficulties in engaging this portion of the functional body (4).

There's a complication factor here [...] probably, in the legislative houses, which is the question of the categories of server, we have effective and non-effective servers, the temporary ones, let's say so, although there is a temporary server with 20 years of service, yet, they are temporary, but this also falls in this question of the discontinuity of the business, then, how do you engage a server that does not really feel part of the institution? (Participant 12).

In addition, the increasing reduction of the number of servers, especially effectives, may result in smaller teams in the HRM unit, which would eventually reduce working capacity and, consequently, would have less time for strategic issues (5). There were also references to the relevance of information technology structure geared to HRM solutions, with positive consequences towards the transparency of processes and activities of the area (6). Finally, the reduction of the resources made available for HRM activities and projects (7) was cited as a current constraint, which could decelerate the process of implementation of the strategic HRM strand and hamper the construction of the link between HRM and organizational planning (Vo \& Bartram, 2012).

[...] we are already foreseeing in the next 5 years, we here in administration, a deficit of servers which would eventually be chaotic in 5 years (Participant 10).

And the question of the financial and budgetary resources, is currently affecting our policies, right, today we cannot make selection exams, we cannot do anything (Participant 9).

In regards to the organizational structure, there is an agreement in both legislative houses that there is an excess of hierarchical levels and functional divisions, which in principle could negatively affect the implementation of the SHRM (Fonseca \& Meneses, 2016), since it would be difficult to reach the vertical alignment of HRM (8) and the more homogeneous involvement in the process, 
with a greater engagement of managers and servers (9), as well as a favorable scenario for a high number of interest conflicts (10), which would impact the decisions of the high administration on HRM activities.

[...] speaking of the structure of the house, I find that [...] it is segmented. As any public agency, this presents a difficulty for you to link this activity with strategic objectives (Participant 11).

Still in relation to the structure, a raised positive point is the existence of sectors formally established for the accompaniment of the execution of the strategic planning, with inserted representatives in the administrative units, enclosed those of HRM, a configuration that tends to assist in the alignment of HRM objectives with organizational goals and in the dissemination of a strategic culture (11), similar to that presented by Farndale, Paauwe and Boselie (2010).

[...] I believe that what the house did, I believe this, a work when creating [...] with all the advising net that is constituted by the sectoral offices [...] it started to spread the culture of planning, the culture of alignment, of communication between the direction and the areas, the coordination, then, it worked to ensure the strategic objectives of the institution (Participant 4).

The aspect of the engagement of managers and servers was seen as a challenge, in the sense that there is a need for greater managerial participation in the strategic process, that there is a lack of preparation of middle managers, even in terms of political skills to deal with the complex legislative scenario (12), and low participation of the servers in general, who tend to resist the changes culturally (13). Such statement implies the existence of restrictions for HRM integration (14), since this also depends on the alignment of line managers and the workforce (Guest, 1987).

[...] we work in a political agency, right, then sometimes the line manager has to have a good technician, a training, have competence, but he also has to have the ability to deal with parliamentarians, this is a aspect in which the house still has a deficiency (Participant 13).

The institutional communication was approached under the focus of transparency in the external and internal availability of information. According to the participants, transparent proposals inhibit the use of criteria other than technical by decision-making arenas (15), in addition to being able to facilitate the strategic integration of HRM (16), since the information on the activities of the area would flow more easily for the diverse sectors of the house.

Moreover, you have the transparency, the transparency is the great ally of the managements, because an action that, just because you let it show, it purifies itself, so to speak, right, it already leaves all the negative ballasts that it could have at a decision level, and then you can also direct the thing to ethical form, to the proper form, to the honest form, to the clean, public, impersonal form (Participant 8). 
Authors as Lodge and Hood (2003) emphasize that environments that discourage the free flow of ideas and criticism and have restrictions on communication and information sharing may be related to poor sensitivity to the external environment and problems of teamwork and intergroup dynamics, factors identified by them as possible causes of the imperfection in the implementation of strategic models of HRM.

The last aspect of organizational nature are the internal norms, whose bigger part of the recurrences refer to the difficulty to promote changes in the HRM that do not need alterations in the existing internal regulation or even the elaboration of new norms, which can often slow down innovations, since, for normative modifications, the HRM units often depend on deliberations by higher authorities, which reduce the freedom of action (17).

$[\ldots]$ and you have that... before anything in the public service, to work the regularization of this, this project, and later the implementation of actions (Participant 7).

However, some participants understand that the internal normatization of action plans of HRM units, after attainment of support of the adjusted instance, could work as a planning for change, as well as help to lead to a kind of a forced persuasion of the actors and groups involved, mitigating possible political barriers (18), similarly to what occurred in the implementation of the strategic management in the Chamber of Deputies (Guimarães et al., 2012).

I already saw here the norm and the legislation as, like, you normatize what you want, not as new, a not preexisting one, you want to make something and then you normatize, because I find here important [...] for example, which is a political house then I think it's important to normatize, even though some things get paralyzed, but for you to try to follow that there, since we are always obeying the legality principle, then if you normatize the things, place them it in the right way, as it should be done, I think that facilitates for us to achieve and to even show this to political sphere (Participant 10).

To sum up and in line with the contextual literature of HRM (Hendry \& Pettigrew, 1990; Paauwe, 2004), in a hypothetical scenario of adoption of the SHRM principles in the Federal Legislative, the evidences demonstrate that, possibly, the organizational reality would be, to a large extent, responsible for the contingencies the units of HRM would come across, because these are a part and a reflection of the organization, with impacts mainly on the interests considered in the political configuration, the level of engagement of managers and servers and in the strategic integration of the HRM (to see Figure 5). 
FIGURE 5 THEORETICAL-EMPIRICAL MODEL OF INTERFERENCES EXERTED BY THE ORGANIZATIONAL ASPECTS

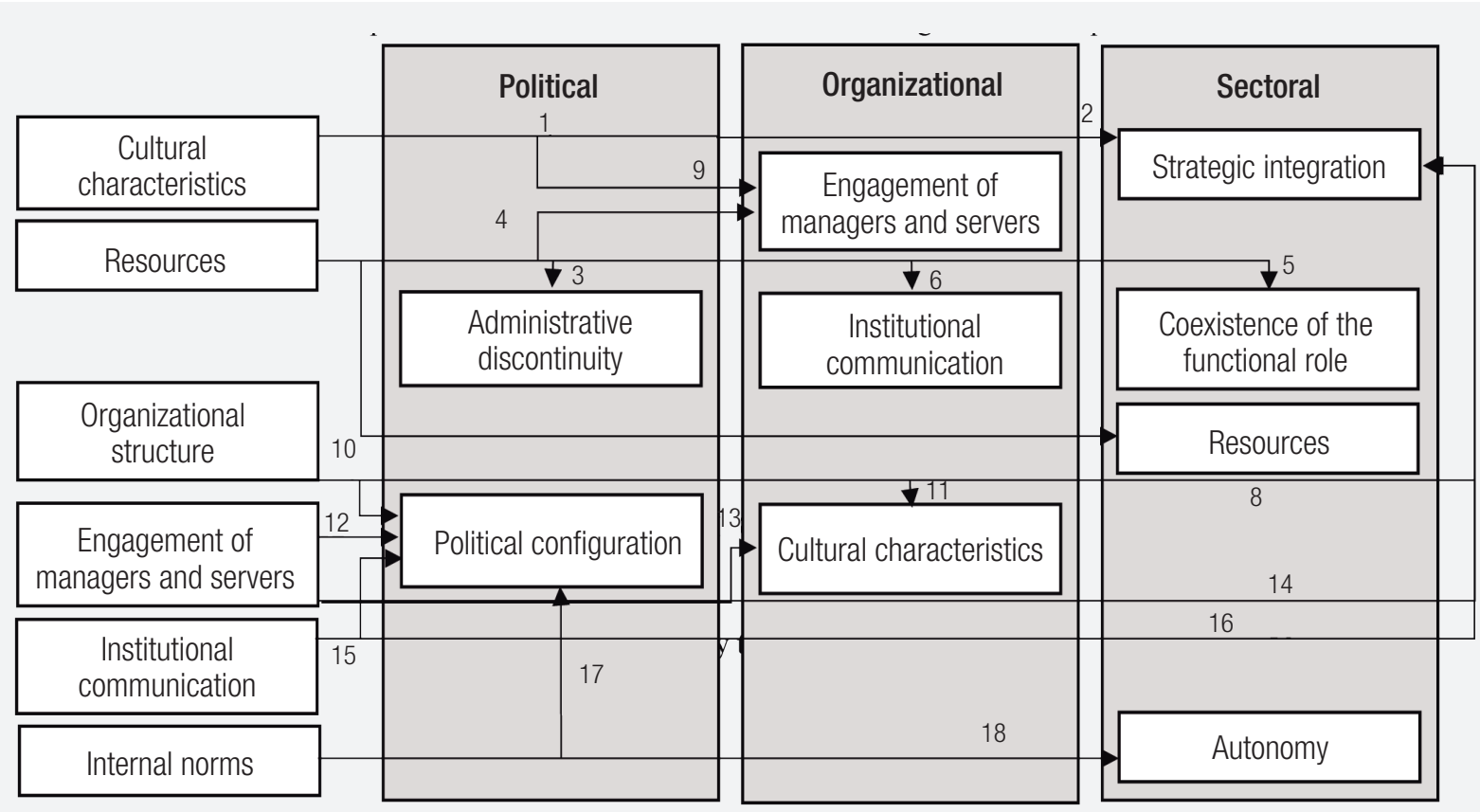

Source: Elaborated by the authors.

In the sectoral category, regarding the HRM strategic integration aspect, the participants understand that there is a gap between what it is established in the strategic planning and what it is carried out, so that some activities are developed by HRM units without even being in the plan, besides the goals set for the area are not reached.

I don't like it, it's awkward to be speaking about the negative suppositions, right? But, between what have been done and what we managed to put in practice [...] it is... we notice that... abyss is a big word, way too big, right? But there's a gap, between what we have here and what we really manage to put in practice, absorb, incorporate, internalize (Participant 1).

Such fact can undermine the reputation of the sector (1), since there are indications that this is composed, for example, by the perception of the high administration members have about the accomplishment of their expectations, given that they tend to expect just that the HRM unit develops activities that help to achieve organizational goals (I. G. L. Souza, 2016; Tsui \& Milkovich, 1987).

Concerning the reputation of the HRM unit, the majority understood that the areas of HRM of the National Congress suffer from problems related to the disregard and lack of perception of importance and recognition, often coming from the political leadership (2), with posterior dissemination for the hierarchical and server levels, which harms the capacity to attract workforce from other sectors and to retain the team that already owns (3), in addition to sometimes causing the preterition of the HRM units in decisions regarding the allocation of resources adopted by the high administration (4).

Today, I already heard people who "I was thinking about leaving, to go to another area", "ah, let's go to HRM unit", "not, less the HRM unit" [laughs], "all less there", why? Because one can see there 
as an area that has much work, and it is not valued. At the end, you still can leave as a person who was guilty of something (Participant 14).

In regards to the HRM unit resources aspect, the already reported scarcity of servers in the organization is also reflected in the HRM units, as there is little workforce and a tendency to decrease, causing slownesss in the treatment of HRM processes and concentration of the team in the activities concerning the functional role of HRM (5), which should be prioritized by legal and normative matters. Another aspect indicated was the experience of the servers who integrate the units that, together with their technical competencies, may be fundamental for the effective transition to SHRM (6) (Fonseca \& Meneses, 2016; Vo \& Bartram, 2012).

There is no point of you go like: "ah, I am going to conceive here a HRM that is the best thing in the world", the institution does not have servers, there is one who works with retirement processes, if he quits, it will be delivery, each one goes there and makes his process, then, I have a HRM that's basic, then I find that this is a preponderant factor, and a negative one (Participant 9).

In regards to the HRM unit autonomy, it is perceived as being low by the HRM managers, since the area would be merely propositive, with a limited participation in decisions that involve it and without freedom and independence to carry out relevant activities, with possible restrictions for vertical alignment (7) and, consequently, for HRM integration (Fonseca et al., 2013; Vo \& Bartram, 2012).

$[\ldots]$ the unit does not have force to decide what to do [...] as the area [...] it is propositive, it does not participate of the movement of a server, it does not participate of these decisions that make up the HRM happens in practice, there is nothing one can do to make it happen (Participant 5).

In regards to the HRM unit structure aspect, there are indications that the hierarchic positioning of the HRM units of the Federal Senate and the Chamber of Deputies is advantageous, since they are directly subordinated to the General-Direction, the body responsible for most administrative decisions of the houses and the expenditure, which can indicate a relative degree of formal autonomy (8) (Fonseca, 2013). Another structural issue is the fact that the HRM has also been recognized as overly hierarchical and segmented, which hinders the reach of a greater integration between the subunits and, of course, greater alignment between subsystems (9).

[...] this influences directly, in terms of hierarchical structure, let's say like that, the organogram chart if we go... in the case of the HRM it's very well positioned (Participant 6).

[...] this segmentation that exists, then, even inside of the sector, that is already small, but it has a hierarchization, that is, lots of subdivisions, I already tried to horizontalize a bit more this organization of the department, right, because I find, to see if I would make, I would promote this bigger interaction between the sectors, to break these walls (Participant 1).

Another sectoral aspect is the implementation methodology, with most reports considering that the SHRM implementation in the Federal Legislative would have to be contextualized with the organization's strategy and with the specificities of that environment, because in previous attempts 
of implementing strategic models of HRM, the complexity and the inadequacy of these led to lack of effectiveness and posterior abandonment, caused by the lack of engagement of the servers (10).

[...] I would say so, it was designed in the way that would be so, great, that would be outstanding, but it was not pragmatic [...] bumped into issues in the house that were not overcome and I do not believe they will be overcome (Participant 7).

The final sectoral aspect is the coexistence of the functional role of the HRM, in reference to the excess of time spent with the more traditional and operational HRM activities, which causes the area to direct less efforts to a more strategic role, what can be an obstacle to the vertical alignment (11). The possible interferences promoted by the aspects of the sectoral category are represented in Figure 6 .

[...] if we were going to set a percentage there, from one to another, I think it would be 60 for part of procedures and 40 for the strategic part, because you see, you cannot detach one thing from another (Participant 6).

As a result, one can assume that, although the sectoral factors result from the complex relationship between the institutional, political and organizational ones, it also is possible that they influence the support of the high administration and the political configuration, by means of the construction of a positive reputation with groups of interest that belong to the superior instances and assist in more engagement of managers and servers, provided that the implementation methodology is consistent with the organizational reality.

FIGURE 6 THEORETICAL-EMPIRICAL MODEL OF INTERFERENCES EXERCISED BY SECTORAL ASPECTS

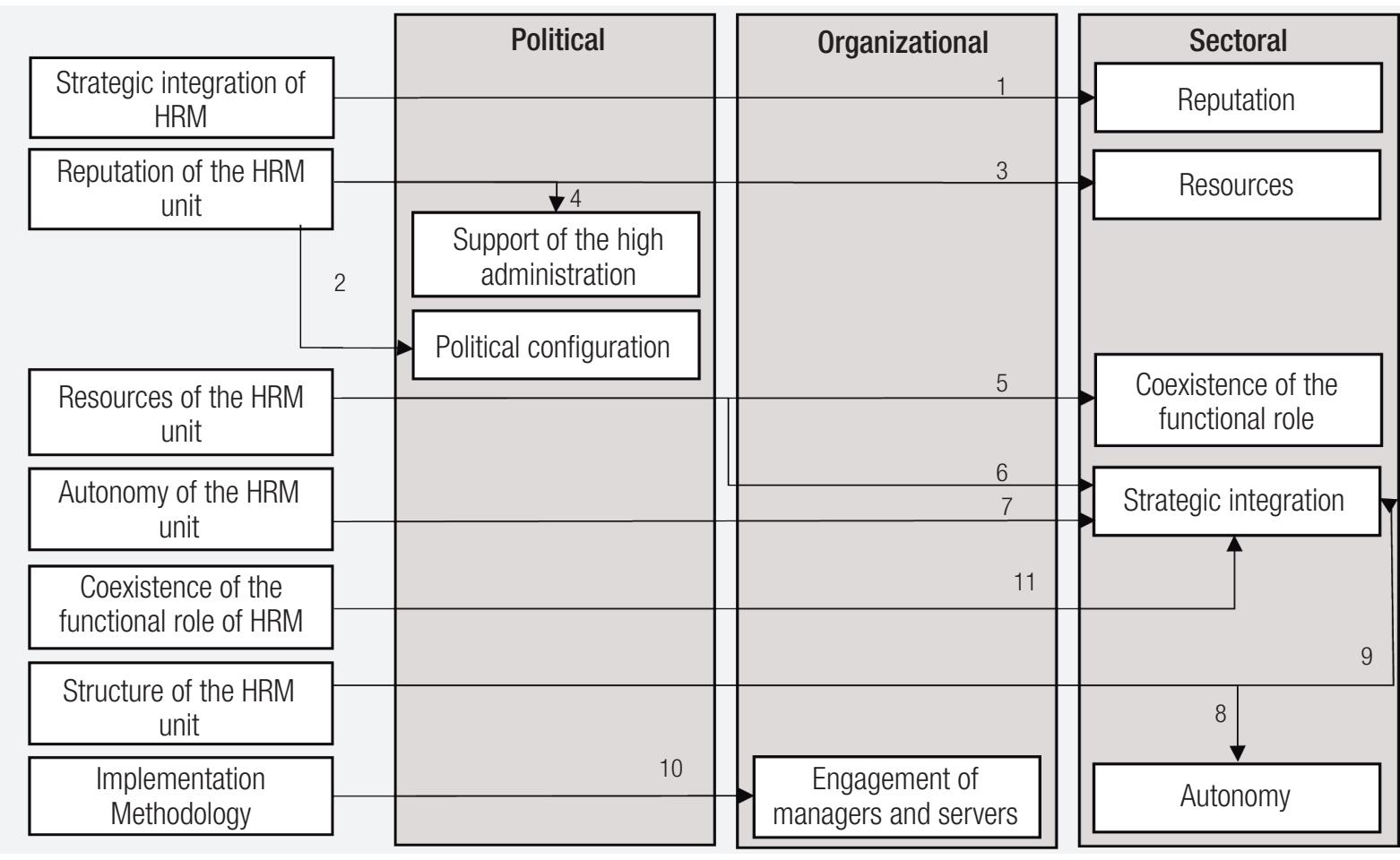

Source: Elaborated by the authors. 
From a broader and more integrated analysis of what has been discussed up to now, from the point of view of the categories of aspects, there seems to be a kind of chain of relations in which the institutional environment influences mostly the political (Fonseca et al., 2013; Fonseca \& Meneses, 2016; Iles, Almhedie, \& Baruch, 2012), especially regarding the formation of the agenda and the conditioning of the decision-making process.

This political decision-making process, in turn, models the organizational reality (Fonseca \& Meneses, 2016) and, consequently, sectoral (Ingraham \& Rubaii-Barrett, 2007; Järvalt \& RandmaLiiv, 2010; Truss, 2008). In his turn, the organizational context conditions the resources and structure held by the HRM unit, as well as its level of strategic integration (Camões \& Meneses, 2016; Farndale et al., 2010; Fonseca \& Meneses, 2016; Jacobson et al., 2014; Lodge \& Hood, 2003; Randma-Liiv \& Järvalt, 2011; Silva \& Mello, 2013; Teo, 2002; Vo \& Bartram, 2012).

Nevertheless, as well as in the proposal of Hendry and Pettigrew (1990) for a contextualized HRM (Figure 1), it is noticed possible presence of a feedback process where the reputation of the unit of HRM can make with that the decisions on it can be changed (I. G. L. Souza, 2016; Teo, 2002; Tsui, 1987; Tsui \& Milkovich, 1987), as the simplified hypothetical model presented in Figure 7.

\section{FIGURE 7 SIMPLIFIED HYPOTHETICAL MODEL OF RELATIONS CHAIN BETWEEN CATEGORIES OF ASPECT}

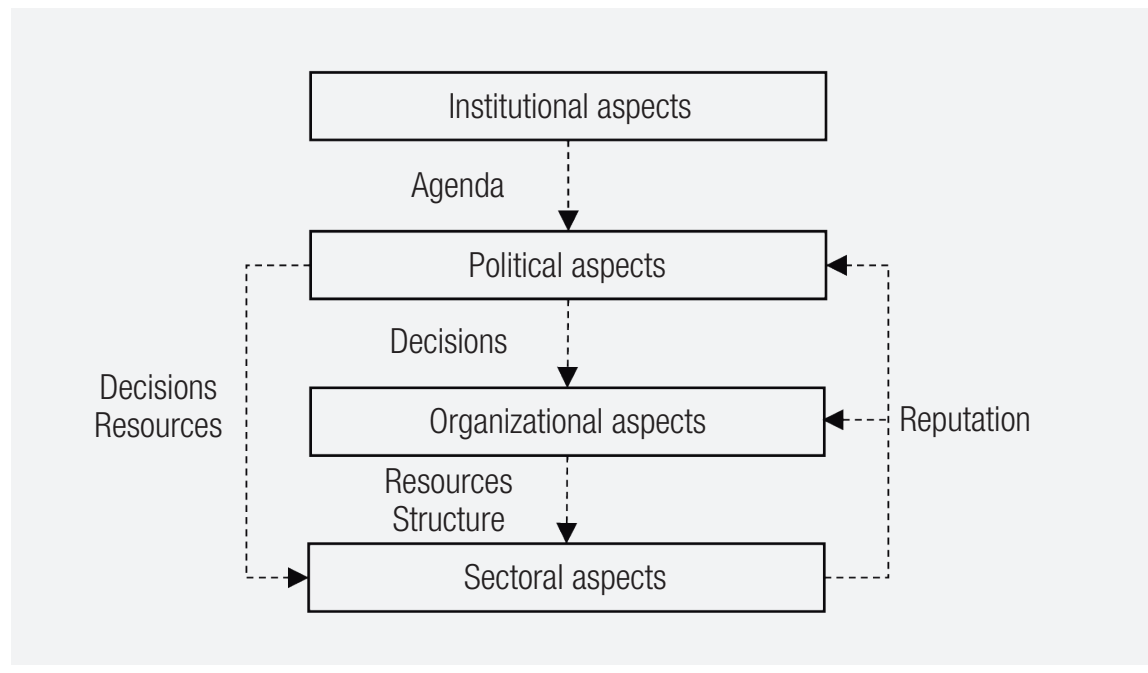

Source: Elaborated by the authors.

Given the scanned scenario, it is assumed that perhaps the political factors are the most sensitive for the SHRM implementation in the legislative houses, as already pointed out in the literature (Cinnanti, 2011; Guimarães et al., 2015), since the favorable decisions to new HRM policies and practices by high administration, that enables a successful implementation, based on the availability of resources and autonomy, factors already identified by other studies as decisive in the public sector (Camões And Meneses, 2016, Fonseca et al., 2013, Fonseca \& Meneses, 2016, Vo \& Bartram, 2012). 
In addition, among the political aspects, there are two that directly affect the level of HRM strategic integration, SHRM's basic principle (Guest, 1987): the political configuration, usually responsible for HRM decisions that are out of alignment with organizational objectives; and the administrative discontinuity, which usually leads to the premature interruption of long-term initiatives conducted by the HRM unit.

It is also inferred that the most relevant obstacles, as already explained, and the possibilities of circumventing them, are political in nature, since, apparently, it is through political skills that the leaders of the HRM areas may well act to leverage their reputation and garner sponsorship from the top and, consequently, autonomy and resources.

Finally, with the results of this study, it was possible to better understand the context to which the HRM is submitted in the Federal Legislative Branch, with the observation that, possibly, the politics would be a pressing aspect in the case of the adoption of the SHRM principles. However, it is important to note that the considerations now made, in order to have a better theoretical-empirical basis, require further investigation into the proposed relations and models, as well as the effects of the politics in the HRM, since this interface is still an issue little studied (Drory \& Vigoda-Gadot, 2010).

\section{FINAL CONSIDERATIONS}

This study aimed to identify the interferants related to the adoption of the SHRM principles in the Brazilian Federal Legislative, as well as to elaborate theoretical-empirical and hypothetical-deductive models about the relations between them, showing the supposed existence of 21 interfering aspects, divided between institutional, political, organizational and sectoral, interconnected through 46 possible relationships.

Based on the findings and the proposed models, it was inferred that the political aspects are apparently the ones that condition and interfere the most in the Brazilian federal legislative houses' HRM, similar to what was already proposed in the literature, and this type of aspect also seems to influence to a great extent the organizational and sectoral ones.

Academically, this study contributes to a better understanding of the context in which the HRM is inserted in the Brazilian Federal Legislative, a topic still little explored scientifically (Araújo \& Silva, 2012). From the practice's point of view, a diagnosis was provided on the contextual constraints that would impact the adoption of SHRM principles, so that legislative organizations can use the results presented here to improve their HRM policies and practices and, consequently, its results, which may help to reverse the situation in which the Legislative appears as a power with the worse evaluation with society (Lamari, 2010).

Regarding the limitations, the research could have benefited from other theoretical frameworks, such as institutional theory and the resource-based view, which would provide greater wealth of data analysis and consequently discussion of results. In addition, the sample could have been composed of some of the actors and interest groups with which HRM units relate, in order to complement the opinions of the managers of the area. Finally, it should be emphasized that the categories resulting from the content analysis process and the proposals of the framework and the theoretical-empirical models of relations between aspects could have undergone a process of validation by judges (professionals and academics), so that the proposed relationships could be improved. 
RAP $\quad$ Strategic human resource management in the Brazilian Federal Legislative: conditions for the implementation

Thus, later studies can retake the Legislative as an object of research and use diverse theoretical foundations, with the formation of samples that contain individuals from different units and hierarchical positions within the organizations, perhaps more focused on the political aspects, apparently so influential in this scenario.

In addition, future research may investigate more closely each of the identified aspects, with the possibility of proposing constitutive and operational definitions. The probable associations between identified interfering aspects, with verification of mediation and moderation relationships, can also be scanned, tested and validated.

After all, it is evident that the reality of the Federal Legislative Power is complex and influenced by its political configuration, which may present HRM managers with challenges to promote changes and improvements in their practices, a scenario in which political skills and competencies may be relevant to greater insertion and participation in decisions that impact the area. 


\section{REFERENCES}

Anselmi, L., Lazzini, S., \& Zarone, V. (2013). Institutional reform and public sector change: from knowledge and competence to accountable public management. Journal of US-China Public Administration, 10(9), 821-833.

Araújo, S. M. V. G., \& Silva, R. S. (2012). Reflexões e novas agendas de pesquisa para os estudos legislativos no Brasil. Revista Ibero-Americana de Estudos Legislativos, 2, 58-74.

Armond, L. P., Côrtes, F. G., Santos, F. A. M., Demo, G., \& Meneses, P. P. M. (2016, Setembro). Gestão estratégica de pessoas: revisão da produção nacional de 2006 a 2015 e agenda de pesquisa para o contexto brasileiro. In Anais do 40 Encontro da Associação Nacional dos Programas de Pós-Graduação em Administração. Mata de São João, BA.

Bardin, L. (2011). Análise de conteúdo. Lisboa, Portugal: Ed. 70.

Bergue, S. T. (2014). Gestão estratégica de pessoas no setor público. São Paulo, SP: Atlas.

Bonder, A., Bouchard, C.-D., \& Bellemare, G. (2011). Competency-based management: an integrated approach to human resource management in the Canadian public sector. Public Personnel Management, 40(1), 1-10.

Boyett, I., \& Currie, G. (2001). The failure of competence-based management education in the public sector: a problem of generic transfer or implementation? Personnel Review, 30(1), 42-60.

Brans, M., \& Hondeghem, A. (2005). Competency frameworks in the Belgian governments: causes, construction and contents. Public Administration, 83(4), 823-837.

Brown, K. (2004). Human resource management in the public sector. Public Management Review, 6(3), 303-309.

Camões, M. R. S. (2013). Análise do processo de implementação da Política Nacional de Desenvolvimento de Pessoal (Master Thesis). Universidade de Brasília, Brasília, DF.

Camões, M. R. S., Fonseca, D. R., \& Porto, V. (2014). Apresentação. In M. R. S. Camões, D. R. Fonseca, \& V. Porto (Orgs.), Estudos em gestão de pessoas no serviço público (pp. 5-9). Brasília, DF: Escola Nacional de Administração Pública.
Camões, M. R. S., \& Meneses, P. P. M. (2016). Gestão de pessoas no governo federal: análise da implementação da política nacional de desenvolvimento de pessoal. Cadernos ENAP, 45, 3-101.

Cascio, W.F. (2015). Strategic HRM: too important for an insular approach. Human Resource Management, 54(3), 423-426.

Cinnanti, C. J. J. (2011). A (des)confiança do cidadão no Poder Legislativo e a qualidade da democracia no Brasil. E-Legis, 6, 84-95.

Cooper, D. R., \& Schindler, P. S. (2014). Business research methods. Nova York, NY: McGraw-Hill.

Creswell, J. W. (2014). Research design: qualitative, quantitative, and mixed method approaches. London, England: SAGE.

Daley, D. M., \& Vasu, M. L. (2005). Supervisory perceptions of the impact of public sector personnel practices on achievement of multiple goals. The American Review of Public Administration, 35(2), 157-167.

Delery, J.E., \& Doty, D. H. (1996). Modes of theorizing in strategic human resource management: tests of universalistic, contingency, and configurational performance predictions. Academy of Management Journal, 39(4), 802-835.

Drory, A., \& Vigoda-Gadot, E. (2010). Organizational politics and human resource management: a typology and the Israeli experience. Human Resource Management Review, 20, 194-202.

Farndale, E., Paauwe, J., \& Boselie, P. (2010). An exploratory study of governance in the intra-firm human resources supply chain. Human Resource Management, 49(5), 849-868.

Farnham, D., \& Stevens, A. (2000). Developing and implementing competence-based recruitment and selection in a social services department: a case study of West Sussex county council. International Journal of Public Sector Management, 13(4), 369-382.

Flick, U. (2007). Designing qualitative research. London, England: SAGE.

Fonseca, D. R. (2013). Autonomia de unidades de gestão de pessoas para desempenho das atividades estratégicas de capacitação na Administração Pública Federal (Master Thesis). Universidade de Brasília, Brasília, DF. 
Fonseca, D. R., \& Meneses, P. P. M. (2016). Fatores para implantação e desenvolvimento da gestão por competências em agências reguladoras federais. Revista Eletrônica Científica da UERGS, 2(2), 117 133.

Fonseca, D. R., Meneses, P. P. M., Silva, A. I., Filho, \& Campos, N. G. (2013). Autonomia para gestão estratégica de pessoas no setor público federal: perspectivas de análise e agenda de pesquisa. Revista de Administração Pública, 47(6), 1451-1475.

Guest, D. E. (1987). Human resource management and industrial relations. Journal of Management Studies, 24(5), 503-521.

Guimarães, A. S., Schwartz, F. P., Souza, J. W., Melo, M. R. M., \& Teixeira, R. V. (2012). Gestão estratégica no Poder Legislativo: o caso da Câmara dos Deputados. Revista do Serviço Público, 63(1), 25-42.

Guimarães, A., Schwartz, F. P., Werneck, J. S., \& Melo, R. M. (2015). Strategic management in legislative public management: a comparative perspective. International Business and Management, 11(1), 13-24.

Hall, M., \& Holt, R. (2008). New public management and cultural change: the case of UK public sector project sponsors as leaders. In P. Windrum, \& P. Koch (Eds.), Innovation in public sector services: entrepreneurship, creativity and management (pp. 21-40). Bodmin, England: MPG.

Hammerschmid, G., \& Walle, S. V. (2011). The impact of the new public management: challenges for coordination and cohesion in European public sectors. Halduskultuur - Administrative Culture, 12(2), 190-209.

Harris, L. (2005). UK public sector reform and the "performance agenda" in UK local government. Personnel Review, 34(6), 681-696.

Hendry, C., \& Pettigrew, A. (1990). Human resource management: an agenda for the 1990s. The International Journal of Human Resource Management, 1(1), 17-43.

Hondeghem, A., Horton, S., \& Scheepers, S. (2006). Modelos de gestão por competências na Europa. Revista do Serviço Público, 57(2), 241-258.

Hood, C. (1991). A public management for all seasons? Public Administration, 1991(69), 3-19.
Iles, P., Almhedie, A., \& Baruch, Y. (2012). Managing HR in the Middle East: challenges in the public sector. Public Personnel Management, 41(3), 465-492.

Inácio, M., \& Rennó, L. (2009). Estudos legislativos no Brasil. In M. Inácio, \& L. Rennó (Org.), Legislativo brasileiro em perspectiva comparada (pp. 17-32). Belo Horizonte, MG: Ed. UFMG.

Ingraham, P. W., \& Rubaii-Barrett, N. (2007). Human resource management as a core dimension of public administration. Retrieved from https://faculty.cbpp. uaa.alaska.edu/afgjp/PADM601\%20Fall\%202009/ FPA-HRM-Article.pdf.

Jackson, S. E., Schuler, R. S., \& Jiang, K. (2014). An aspirational framework for strategic human resource management. The Academy of Management Annals, 8(1), 1-56.

Jacobson, W. S., Sowa, J. E., \& Lambright, K. T. (2014). Do human resource departments act as strategic partners? Strategic human capital management adoption by county governments. Review of Public Personnel Administration, 34(3), 289-301.

Järvalt, J., \& Randma-Liiv, T. (2010). Public sector HRM: the case of no central human resource strategy. Baltic Journal of Management, 5(2), 242-256.

Lacombe, B. M. B., \& Tonelli, M. J. (2001). O discurso e a prática: o que nos dizem os especialistas e o que nos mostram as práticas das empresas sobre os modelos de gestão de recursos humanos. Revista de Administração Contemporânea, 5(2), 157-174.

Lamari, R. (2010). Reforma do Legislativo. Cadernos Adenauer, 11(1), 38-50.

Leite, N. R. P., \& Albuquerque, L. G. (2011). Gestão estratégica de pessoas, comprometimento e contrato psicológico: o caso Vale. Revista de Administração da USP, 46(1), 19-31.

Lem, R. B. K. (2011). Evidence of strategic human resource management practice in a public sector organization: a content analysis of the HRM policy and strategy of the ministry of health of Ghana, 2007-2011. Health Policy And Development, 9(1), 7-16.

Lengnick-Hall, C. A., Beck, T. E., \& Lengnick-Hall, M. L. (2011). Developing a capacity for organizational resilience through strategic human resource management. Human Resource Management Review, $21,243-255$. 
Lengnick-Hall, M. L., Lengnick-Hall, C. A., Andrade, L. S., \& Drake, B. (2009). Strategic human resource management: the evolution of the field. Strategic Human Resource Management, 19, 64-85.

Lima, M. A. M., \& Lima, I. V. (2013). A gestão por competência e as funções de recursos humanos: estudo de caso na Universidade Federal do Ceará (UFC). Revista Ciências Administrativas, 19(2), 698-740.

Lodge, M., \& Hood, C. (2003). Competency and bureaucracy: diffusion, application and appropriate response? West European Politics, 26(3), 131-152.

Marler, J. H., \& Fisher, S. L. (2013). An evidencebased review of e-HRM and strategic human resource management. Human Resource Management Review, 23, 18-36.

Mello, M. L. B. C., \& Amâncio, A., Filho. (2010). A gestão de recursos humanos em uma instituição pública brasileira de ciência e tecnologia em saúde: o caso Fiocruz. Revista de Administração Pública, 44(3), 613-636.

Mesch, D. J.; Perry, J. L.; \& Wise, L. R. (1995). Bureaucratic and strategic human resource management: an empirical comparison in the federal government. Journal of Public Administration Research and Theory, 5(4), 385-402.

Motta, P. R. M. (2013). O estado da arte da gestão pública. Revista de Administração de Empresas, 53(1), 82-90.

Paauwe, J. (2004). HRM and performance: achieving long term viability. New York, NY: Oxford University Press.

Peci, A., Pieranti, O. P., \& Rodrigues, S. (2008). Governança e new public management: convergências e contradições no contexto brasileiro. Organizações \& Sociedade, 15(46), 39-55.

Pichault, F. (2007). HRM-based reforms in public organizations: problems and perspectives. Human Resource Management Journal, 17(3), 265-282.

Randma-Liiv, T., \& Järvalt, J. (2011). Public personnel policies and problems in the new democracies of Central and Eastern Europe. Journal of Comparative Policy Analysis: Research and Practice, 13(1), 35-49.

Ring, P. S., \& Perry, J., L. (1985). Strategic management in public and private organizations: implications of distinctive contexts and constraints. Academy of Management Review, 10(2), 276-286.

Sheehan, C., Cieri, H., Cooper, B. K., \& Brooks, R. (2015). The impact of HR political skill in the HRM and organisational performance relationship. Australian Journal of Management, 41(1), 161-181.

Silva, F. M., \& Mello, S. P. T. (2013). A implantação da gestão por competências: práticas e resistências no setor público. Revista Eletrônica de Administração e Turismo, 2(1), 110-127.

Šiugždinienè, J. (2006). Competency management in the context of public management reform. Viešoji Politika Ir Administravimas, 18, 26-33.

Souza, I. G. L. (2016). Reputação das áreas de recursos humanos (Master Thesis). Universidade de Brasília, Brasília, DF.

Souza, R. L. S. (2004, noviembre). Gestão por competências no governo federal brasileiro: experiência recente e perspectivas. In Anales del 90 Congreso Internacional del CLAD sobre la Reforma del Estado y de la Administración Pública. Madrid, España.

Teixeira, H. J., Bassotti, I. M., \& Santos, T. S. (2013). Uma palavra dos organizadores. In H. J. Teixeira, I. M. Bassotti, \& T. S. Santos (Orgs.), Contribuições para a gestão de pessoas na administração pública (pp. 11-27). São Paulo, SP: Fundação Instituto de Administração \& Universidade de São Paulo.

Teo, S. T. T. (2002). Effectiveness of a corporate HR department in an Australian public-sector entity during commercialization and corporatization. The International Journal of Human Resource Management, 13(1), 89-105.

Terabe, C. P. A. R., \& Bergue, S. T. (2014). Gestão estratégica de pessoas como política pública: estudo de caso no Ministério da Ciência, Tecnologia e Inovação. In M. R. S. Camões, D. R. Fonseca, \& V. Porto (Orgs.), Estudos em gestão de pessoas no serviço público (pp. 11-37). Brasília, DF: Escola Nacional de Administração Pública.

Tran, B. (2015). Triangulation in organizational research: validating knowledge in human competence at work. In A. Takhar-Lail, \& A. Ghorbani (Eds.), Market research methodologies: multi-method and qualitative approaches (pp. 93-117). Hershey, PA: Business Science Reference. 
RAP $\quad$ Strategic human resource management in the Brazilian Federal Legislative: conditions for the implementation

Truss, C. (2008). Continuity and change: the role of the HR Function in the modern public sector. Public Administration, 86(4), 1071-1088.

Tsui, A. S. (1987). Defining the activities and effectiveness of the human resource department: a multiple constituency approach. Human Resource Management, 26(1), 35-69.

Tsui, A. S., \& Milkovich, G. T, (1987). Personnel department activities: constituency perspectives and preferences. Personnel Psychology, 40, 519-537.

Ubeda, C. L., \& Santos, F. C. A. (2008). Os principais desafios da gestão de competências humanas em um instituto público de pesquisa. Gestão \& Produção, 15(1), 189-199.

Vo, A., \& Bartram, T. (2012). The adoption, character and impact of strategic human resource management: a case study of two large metropolitan Vietnamese public hospitals. The International Journal of Human Resource Management, 23(18), 3758-3775.

Wright, P. M., \& McMahan, G. C. (1992). Theoretical perspectives for strategic human resource management. Journal of Management, 18(2), 295-320.

\section{Felipe Guimarães Côrtes}

https://orcid.org/0000-0001-9899-8080

Master of Business Administration from the University of Brasília (UnB); Professor at the School of Administration of Brasília of the Brazilian Institute of Public Law (EAB/IDP). E-mail: fgcortes@gmail.com

\section{Pedro Paulo Murce Meneses}

https://orcid.org/0000-0002-6937-3302

$\mathrm{PhD}$ in Psychology from the University of Brasília (UnB); Professor in the Postgraduate Program in Administration of the University of Brasília (PPGA/UnB).E-mail: pemeneses@yahoo.com.br 